\title{
LONG-TERM RESULTS FOR THE TREATMENT OF PATIENTS WITH THE APPLICATION OF ORGAN-PRESERVING OPERATIONS IN PAPILARY THYROID CANCER
}

\author{
Alika Korkelia \\ Institute of Problems of Endocrine Pathology named after V. Ya. Danilevsky of National Academy of \\ Medical Sciences of Ukraine, 10 Alchevsk St., Kharkiv, 61002, Ukraine, e-mail: ipep@ vl.kharkov.ua
}

In order to analyse the changes in the structural and functional state of the thyroid gland, a group of 185 patients $(67.8 \%)$ were examined after the surgical treatment of papillary thyroid cancer. Of these, 94 patients belonged to the first group - the comparison group where thyroidectomy was performed, and 91 to the second - the main group where, mainly, organ-preserving operations were performed. The average follow-up was $6.5 \pm 5.1$ years (varied from 2 to 11 years.

Hypoparathyroidism in patients receiving replacement therapy was observed in $20(16.4 \%)$ patients after thyroidectomy and only in $4(6.3 \%)$ patients after organ-preserving techniques (the differences are significant, $\mathrm{p}<0.05)$. Side effects of replacement therapy were observed in $21(17.2 \%)$ patients after thyroidectomy and only in $4(6.3 \%)$ patients after organ-preserving techniques (the differences are significant, $\mathrm{p}<0.05)$. Disease recurrence was detected in $4(3.3 \%)$ patients after thyroidectomy and in 1 $(1.6 \%)$ patient after organ-preserving techniques (the differences are not significant, $p>0.05$ ).

The use of organ-preserving approaches in the main group allowed improving functional results by reducing the frequency of hypothyroidism and side effects of replacement therapy, due to the preservation of thyroid secretion and its regulation, without worsening the results of relapse-free survival.

KEY WORDS: organ-preserving interventions, papillary thyroid cancer, long-term results of treatment

\section{ВІДДАЛЕНІ РЕЗУЛЬТАТИ ЛІКУВАННЯ ХВОРИХ З ВИКОРИСТАННЯМ ОРГАНОЗБЕРІГАЮЧИХ ОПЕРАЦІЙ ПРИ ПАПІЛЯРНОМУ РАКУ ЩИТОПОДІБНОЇ ЗАЛОЗИ}

\section{Коркеліа А. Г.}

Інститут проблем ендокринної патології ім. В. Я. Данилевського АМН України, вул. Алчевських, 10, м. Харків, 61002, Україна

3 метою аналізу змін структурно-функціонального стану щитовидної залози у віддалений термін після оперативного лікування папілярного раку щитоподібної залози була обстежена група 3 185 хворих (67,8 \%). 3 них 94 хворих належали до першої групи - групі порівняння де виконували тиреоідектомію, а 91 до другої - основної групі, де, здебільшого, виконували органощадні операції. Середній термін спостереження склав $6,5 \pm 5,1$ років (варіював від 2 до 11 років).

Гіпопаратиреоз на тлі прийому замісної терапії було відмічено у 20 (16,4\%) хворих після тиреоїдектомії та тільки у 4 (6,3 \%) хворих після органощадних методик (відмінності достовірні, p < 0.05). Побічні ефекти замісної терапії відзначалися у 21 (17,2\%) хворих після тиреоїдектомії та тільки у $4(6,3 \%)$ хворих після органощадних методик (відмінності достовірні, $\mathrm{p}<0.05)$. Рецидив захворювання виявлено у 4 (3,3\%) хворих після тиреоїдектомії та у 1 (1,6\%) хворого після органощадних методик (відмінності недостовірні, $\mathrm{p}>0.05$ ).

Застосування органоощадних підходів в основній групі дозволило поліпшити функціональні результати, зменшивши частоту гіпотиреозу і побічних ефектів замісної терапії, за рахунок збереження тиреоїдної секреції і її регуляції, не погіршуючи результати безрецидивного виживання.

КЛЮЧОВІ СЛОВА: органощадні втручання, папілярний рак щитоподібної залози, віддалені результати лікування 


\section{ОТДАЛЕННЫЕ РЕЗУЛЬТАТЫ ЛЕЧЕНИЯ БОЛЬНЫХ С ПРИМЕНЕНИЕМ ОРГАНОСОХРАНЯЮЩИХ ОПЕРАЦИЙ ПРИ ПАПИЛЯРНОМ РАКЕ ЩИТОВИДНОЙ ЖЕЛЕЗЫ}

Коркелиа А. Г.

Институт проблем эндокринной патологии им. В. Я. Данилевского АМН Украины, ул. Алчевских, 10, г. Харьков, 61002, Украина

С целью анализа изменений структурно-функционального состояния щитовидной железы в отдаленные сроки после оперативного лечения папиллярного рака щитовидной железы была обследована группа из 185 больных (67,8\%). Из них 94 больных принадлежали к первой группе группе сравнения, где выполняли тиреоидэктомию, а 91 ко второй - основной группе где, преимущественно, выполняли органощадящие операции. Средний срок наблюдения составил 6,5 $\pm 5,1$ лет (варьировал от 2 до 11 лет).

Гипопаратиреоз на фоне приема заместительной терапии отмечался у 20 (16,4 \%) больных после тиреоидэктомии и только у 4(6,3 \%) больных после органощадящих методик (различия достоверны, p < 0.05). Побочные эффекты заместительной терапии отмечались у 21 (17,2\%) больных после тиреоидэктомии и только у 4 (6,3 \%) больных после органощадящих методик (различия достоверны, p <0.05). Рецидив заболевания выявлен у 4 (3,3\%) больных после тиреоидэктомии и у 1(1,6\%) больного после органощадящих методик (различия недостоверны, p > 0.05).

Применение органощадящих подходов в основной группе позволило улучшить функциональные результаты, уменьшив частоту гипотиреоза и побочных эффектов заместительной терапии за счет сохранения тиреоидной секреции, и ее регуляции, не ухудшая результаты безрецидивной выживаемости.

КЛЮЧЕВЫЕ СЛОВА: органощадящие вмешательства, папиллярный рак щитовидной железы, отдаленные результаты лечения

\section{INTRODUCTION}

In recent years, there has been a tendency to perform organ-preserving interventions for papillary thyroid cancer (PTC) such as hemithyroidectomy or subtotal resection [1-3]. This approach is considered in tumours with sizes less than 1 centimetre [2,4]. However, for larger tumours, there is no clear agreement on the maximum size of the tumour in which organ-preserving operations can be performed [3].

There are several factors that influence the prognosis of disease recurrence and the tactics chosen by the surgeon during surgical treatment: multimodality, the presence of «aggressive» histological forms of PTC, tumour size, invasion into the capsule, and extrathyroid invasion [2, 5]. In addition, the biological properties of the tumour play an important role $[4,6]$. This study presents an assessment of the long-term results of PTC treatment, where the choice of organ-preserving operations was carried out depending on the prediction of the aggressive behaviour of the tumour, which was determined in accordance with histological and immunohistochemical criteria.

\section{OBJECTIVE}

Evaluation of long-term results of organpreserving operations in patients with papillary thyroid cancer.

\section{MATERIALS AND METHODS}

The work was performed in the State Institution «Institute of Problems of Endocrine Pathology named after V. Ya. Danilevsky of National Academy of Medical Sciences of Ukraine». There were 273 patients under observation with a final diagnosis of PTC. The patients were divided into 2 groups: Group I the comparison group - 155 patients with PTC in whom only thyroidectomy was used. Group II - the main group - 118 patients, where the choice of surgical treatment method thyroidectomy or organ-preserving surgery was carried out according to the developed algorithm. In order to analyse changes in the structural and functional state of the thyroid gland in a long-term period after the surgical treatment, a group of 185 patients $(67.8 \%)$ were examined. Of these, 94 patients belonged to the first group - the comparison group, and 91 to the second - the main group. The average follow-up was $6.5 \pm 5.1$ years (varied from 2 to 11 years). 
The algorithm for choosing the method of operative treatment of patients with PTC: The surgical tactic in the comparison group was to perform thyroidectomy and lymph node dissection in the presence of metastatic lymph nodes in all patients. Surgical tactics in the main group were based on risk factors identified before the operation or after the operation. Hemithyroidectomy was performed on tumours up to $2 \mathrm{~cm}$ in size. If intraoperative histological examination revealed multifocal tumour growth, capsule invasion or extrathyroid invasion, as well as cancer from cylindrical cells, in such patients was performed thyroidectomy. In the postoperative period, resected material investigated immunohistochemicaly with quantitative determination of TTF1, NIS, Ki67. With overexpression of TTF1, the absence of expression of NIS, and the high expression level of Ki67, a repeated operation (total thyroidectomy) was considered to be shown.

\section{RESULTS AND DISCUSSION}

Analysis of the volume of surgical intervention in patients with PTC in the comparison group showed that most of them 64 $(54.6 \%)$ were operated on by organ-preserving techniques. Among 118 patients, only 55 $(46.6 \%)$ had thyroidectomy, the volume of other operations was a subtotal resection of the lobe of the gland in $21(17.8 \%)$ patients, a subtotal resection of the whole gland -9 $(7.6 \%)$, hemithyroidectomy was performed in $17(14.4 \%)$ patients. In $16(13.6 \%)$ patients with a multinodular lesion, hemithyroidectomy on the affected side and subtotal resection on the opposite side were performed.

Of the 185 patients examined in the longterm period, $124(67.02 \%)$ received various types of radiation treatment. Of these, 50 patients $(40.3 \%)$ were treated with remote gamma-therapy on the thyroid bed and the lymphatic drainage path, 56 patients $(45.2 \%)$ were treated with radioactive iodine (from 1 to 4 courses), in 18 patients $(14.5 \%)$ radiation treatments were not used.

Of the 94 patients in the comparison group, a recurrence of thyroid cancer was detected in 3 $(3.2 \%)$ patients from 7 to 1 year after surgery.

From 91 patients of the main group (63 patients where organ-preserving techniques were performed and 28 who underwent total thyroidectomy), additional nodular formations in the residual thyroid tissue, according to ultrasound, were found in six patients $(9.5 \%)$ without an increase in the neck lymph nodes. When performing TAPB in these patients, in four cases, suspicious malignant changes were identified. In two cases, the recurrence of colloidal goiter.

Four patients with suspected malignancy were operated on. At the final histological examination after re-operation, PTC was diagnosed in one patient, in two patients a follicular thyroid adenoma and colloid goiter nodes were detected. In another patient, papillary microcarcinoma was found on the background of a multinodular goiter and a follicular adenoma - with a lesion of malignant growth of up to $4 \mathrm{~mm}$ in size.

Thus, in the late postoperative period, among 91 patients who operated on for PTC, a true recurrence of papillary thyroid cancer was detected only in 1 patient $(1.1 \%) 7$ years after the first operation. Another lymphogenous relapse was detected in a patient undergoing thyroidectomy.

The analysis of follow-up observation of patients with PTC in the postoperative period showed very low patient compliance. Only the first two or three years the patients regularly visited the endocrinologist, in the future these visits became random. Patients either stopped taking thyroxin at all, or adjusted their dosing to their own sensations. As a result, out of 141 patients who received replacement therapy, only $38(27 \%)$ took thyroxin preparations in maintenance dosages.

An important problem was also the presence of side effects of substitution therapy - such as tachycardia, extrasystole, pressing pain behind the sternum, anxiety, hand tremor that occur after taking thyroxin or 30 minutes later, Considering that none of the patients taking thyroid hormone drugs in the replacement dose did not arise recurrence, then when prescribing hormonal therapy in a suppressive dosage it is necessary to carefully choose between the feasibility of achieving the recommended level of thyrotrophic hormone and the validity of such treatment, giving preference to the latter.

All of the above suggests that the treatment of patients with PTC (surgical treatment in organ-preserving volume, followed by radiation therapy and the use of suppressive drugs), has shown significant effectiveness. That is, removal of the tumour, leaving a small number of thyroid parenchyma, did not adversely affect the incidence of recurrent thyroid cancer. 
At present, some specialists suggest that in case of surgical treatment of PTC, extrafascial thyroidectomy must be supplemented with prophylactic central lymphatic dissection. It is motivated by the fact that micrometastases in regional lymph nodes in patients with PTC occur very often (more than in $50 \%$ of cases). Central lymphodissection is accompanied by an increase in the number of postoperative complications, such as laryngeal paresis and hypoparathyroidism. In the main group, we did not perform prophylactic lymphodissection. Performed only when we had clinically detected lymph node metastases, which were detected in 40 cases $(14.65 \%)$. Observation up to 11 years did not reveal a single case of regional or remote lymphogenous metastasis.

Hypothyroidism in patients receiving replacement therapy was observed in 20 $(16.4 \%)$ patients after thyroidectomy and only in $4(6.3 \%)$ patients after organ-preserving techniques (the differences are significant, $\mathrm{p}<0.05$ ). Side effects of replacement therapy were observed in $21(17.2 \%)$ patients after thyroidectomy and only in $4(6.3 \%)$ patients after organ preserving techniques (the differences are significant, $\mathrm{p}<0.05)$. Disease recurrence was detected in $4(3.3 \%)$ patients after thyroidectomy and in $1(1.6 \%)$ patient after organ preserving techniques (the differences are not significant, $\mathrm{p}>0.05$ ).

These data indicate that the preservation of the parenchyma of the thyroid gland can reduce the frequency of hypothyroidism, as well as reduce the frequency of side effects of replacement therapy by maintaining thyroid secretion and its regulation. The use of organ preserving techniques, according to our data, does not significantly affect the risk of tumour recurrence.

\section{CONCLUSIONS}

The use of organ preserving approaches in the main group allowed improving functional results, reducing the frequency of hypothyroidism and side effects of replacement therapy, by maintaining thyroid secretion and its regulation, without worsening the results of relapse-free survival.

\section{PROSPECTS FOR FUTURE STUDIES}

Further study of the long-term results of surgical treatment of patients with papillary thyroid cancer will allow us to individualize the operational tactics and improve the results of treatment.

\section{REFERENCES}

1. Bolhov M. YU. Viddaleni rezul'taty orhanozberihayuchikh operatsiy pry visokodiferentsiyovanikh kartsynoma shchitopodibnoyi zaloza // Endokrinolohiya. - 2009. - T. 14, No. 1. - S. 21-26.

2. Ebina A. Riskadapted management of papillary thyroid carcinoma according to our own risk-group classification sytem: Is thyroid lobectomy the treatment of choice for low-risk patients? / A. Ebina, I. Sugitani, Y. Fujimoto et al. // Surgery. - 2014. - No. 16. - P. 1579-1589.

3. Nixon I. J Thyroid lobectomy for treatment of well differentiated intrathyroid malignancy / I. J Nixon, J. Ganly, S. G Patel. et al. // Surgery. - 2012. - Vol. 151(4). - P. 571-79.

4. Vanushko V.E. Likuvannya dyferentsiyovanoho raku shchytovydnoyi zalozy: stan problem/ V. E. Vanushko., A. YU. Tsurkan // Klyn. eksp. tyreoyid. - 2010. - T. 6, No. 2. - S. 24-33.

5. Mazeh H. Multifocality in well-differentiated thyroid carcinomas calls for total thyroidectomy / H. Mazeh, Y. Samet, D. Hochstein et al. // Am. J. Surg. - 2011, Jun. - Vol. 2016. - P. 770-5.

6. Dubovyk V. M. Viddaleni rezul'taty khirurhichnoho likuvannya papilyarnoho raku shchitopodibnoyi zaloza / V. M. Dubovyk, V. V. Khaziyev, I. V. Hopkalova ta in. // Dosyahnennya ta perspektyvy eksperymental'noyi y Klinichnoyi endokrinolohiyi (Dvanadtsyati Danilevs'ki chytannya): materialy nauk.-prakt. konf. z mizhnar. Uchast', Kharkiv, 14-15 berez. 2013 r. - KH, 2013. - S. 47. 